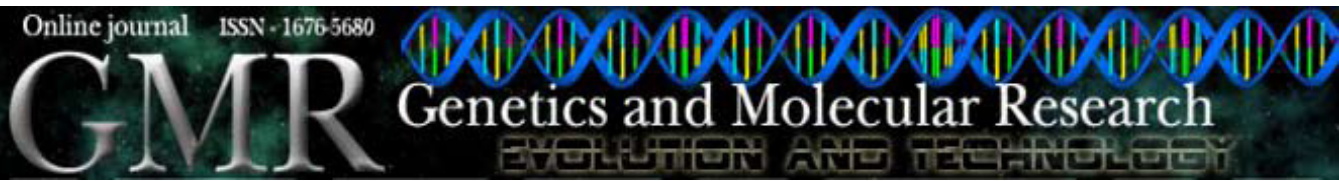

\title{
Anatomy and genetic diversity of two populations of Schinus terebinthifolius (Anacardiaceae) from the Tibagi River basin in Paraná, Brazil
}

\author{
E.A. Ruas ${ }^{1,3}$, C.F. Ruas ${ }^{1}$, P.S. Medri ${ }^{2}$, C. Medri ${ }^{1}$, M.E. Medri ${ }^{2}$, E. Bianchini ${ }^{2}$, \\ J.A. Pimenta ${ }^{2}$ L.A. Rodrigues ${ }^{1}$ and P.M. Ruas ${ }^{1}$ \\ ${ }^{1}$ Departamento de Biologia Geral, Centro de Ciências Biológicas, \\ Universidade Estadual de Londrina, Londrina, PR, Brasil \\ ${ }^{2}$ Departamento de Biologia Animal e Vegetal, Centro de Ciências Biológicas, \\ Universidade Estadual de Londrina, Londrina, PR, Brasil \\ ${ }^{3}$ Departamento de Agronomia, Centro de Ciências Agrárias, \\ Universidade Estadual de Londrina, Londrina, PR, Brasil
}

Corresponding author: E.A. Ruas

E-mail: edu_wicca@yahoo.com.br

Genet. Mol. Res. 10 (1): 526-536 (2011)

Received August 20, 2010

Accepted November 3, 2010

Published March 29, 2011

DOI 10.4238/vol10-1gmr1028

\begin{abstract}
Knowledge of the effects of flooding on plant survival is relevant for the efficiency of management and conservation programs. Schinus terebinthifolius is a tree of economic and ecological importance that is common in northeast Brazil. Flooding tolerance and genetic variation were investigated in two riparian populations of $S$. terebinthifolius distributed along two different ecological regions of the Tibagi River basin. Flooding tolerance was evaluated through the investigation of young plants, submitted to different flooding intensities to examine the morphological and anatomical responses to this stress. The growth rate of $S$. terebinthifolius was not affected by flooding, but total submersion proved to be lethal for $100 \%$ of the plants. Morphological alterations such as hypertrophied lenticels were observed in both populations and lenticel openings
\end{abstract}


were significantly higher in plants from one population. Genetic analysis using DNA samples obtained from both populations showed a moderate degree of genetic variation between populations $(13.7 \%)$; most of the variation was found within populations (86.3\%). These results show that for conservation purposes and management of degraded areas, both populations should be preserved and could be used in programs that intend to recompose riparian forests.

Key words: Flooding; Morphoanatomy; RAPD; Riparian forests

\section{INTRODUCTION}

Plant species adapt to their ever-changing environment, leading to a great diversity of forms and complexity. Some habitats require unusual adaptations, particularly when some resources are scarce or not present at all. Conditions in waterlogged terrains are an example of such extreme environments; water-saturated soils lack oxygen, one of the main resources for plant life (Visser et al., 2003).

The tolerance of riparian species to flooding reveals alterations in the life cycle, in morphology and in functional aspects of the plants (Armstrong, 1980; Voeseneck and Van der Veen, 1994). While morphological and physiological alterations are frequently found in tropical tree species (Medri et al., 2002), aerenchyma (Davanso-Fabro et al., 1998; Medri et al., 2002), hypertrophied lenticels (Bianchini et al., 2000; Medri et al., 2002; Mielke et al., 2005) and adventitious and diageotropic roots (Chen et al., 2002; Medri et al., 2002) are the main responses observed in plants under flooding. Understanding such alterations and their adaptive contributions is important for projects that intend to recover degraded riparian forests. The success of conservation programs depends on the maintenance of genetic resources allied with the reforestation efforts. It is necessary to characterize genetic variation and relate it to the species habitat.

The advent of molecular biology techniques involving polymerase chain reaction (PCR) has allowed direct access to the genetic variability contained in the genome of organisms and made it possible to infer the genetic variability within and among populations of plants. Among the most utilized techniques, random amplified polymorphic DNA (RAPD) stands out as a relatively easy and affordable technique and may be used with any plant species without requiring previous knowledge concerning its genome (Ferreira and Grattapaglia, 1996). Schinus terebinthifolius (Anacardiaceae), commonly known as Brazilian pepper, is a Heliophila evergreen pioneer tree species native to Brazil (Lorenzi, 2002), Paraguay and Northeastern Argentina. Brazilian pepper has become established and naturalized in most tropical and subtropical parts of the world. It has been widely grown as an ornamental but has proven to be extremely invasive. Commonly found on the borders of rivers and lakes and in secondary humid forest formations, this species is especially common in moist, organic soils, but will grow in any soil type. It is salt-tolerant, able to withstand flooding, fire and drought and sprouts easily from the trunk and roots. Typically dioecious, the species is classified as xenogamic (Lenzi and Orth, 2004); the female trees produce small yellowish-white flowers in spring, followed by clusters of small red berries. S. terebinthifolius has a high importance value index $(=4.19)$ along all 
areas of distribution (Melo et al., 2009). The fruits are highly appreciated by birds, which easily spread its seeds. Fruit ripens in the fall and winter months when little or no food is available for the fauna, making this species very useful in heterogeneous reforestations of degraded areas, including those periodically submitted to flooding (Lorenzi, 2002). Besides its ecological importance, S. terebinthifolius has been widely used for therapeutic purposes (Guerra et al., 2000; Melo et al., 2009). The commercial importance of this species is increasing considerably, since the cultivation of the trees is becoming an alternative for agricultural production in many Brazilian states. The seeds are greatly appreciated as spice and demand is increasing, in both internal and external markets. All these attributes make the maintenance of the genetic resources and sustainable use of this species extremely important. We chose $S$. terebinthifolius for our study with the following objectives: 1) to determine if there are differences in anatomy between plants derived from two populations of this species collected from two distinct regions of a river basin in Brazil; 2) to examine the genetic variation within and between populations; 3 ) to determine the levels of genetic variability within these populations to evaluate if they can be used as sources of genetic variation to recover degraded areas.

\section{MATERIAL AND METHODS}

\section{Study area}

Plant material was collected from two riparian forest fragments along the Tibagi River basin in Paraná State, Brazil. These populations are $180 \mathrm{~km}$ from each other and present different levels of conservation. One population came from Imbaú county (2426'42'S, $50^{\circ} 45^{\prime} 39^{\prime}$ 'W, $940 \mathrm{~m}$ altitude), in the middle region of the Tibagi River basin, and the other population was from Londrina county $\left(23^{\circ} 18^{\prime} 37^{\prime}\right.$ 'S, $51^{\circ} 09^{\prime} 46^{\prime \prime} \mathrm{W}$, $585 \mathrm{~m}$ altitude) in the lower Tibagi River basin. The Imbaú location had a lower level of anthropic interference than the Londrina population.

\section{Seed collection, germination and experimental design}

Seeds of S. terebinthifolius were collected from various individuals of the two populations and germinated in a greenhouse. Seeds were planted in $700 \mathrm{~g}$ wet substrate consisting of $80 \%$ soil and a $20 \%$ mixture of grated grass, lime and coffee powder. After 60 days, plants were selected for uniformity in size and transferred to 4-L plastic pots with soil and sand in a 3:1 proportion for another 60 days for acclimatization. One hundred and twenty plants from each population were divided into six treatments and distributed in a green house in a completely randomized design. The treatments were: D30 and D60 (control) - plants were cultivated for 30 or 60 days in drained soil; F30 - plants were cultivated for 30 days in flooded soil; SB30 - plants were submerged for 30 days; SB30/ REA30 - plants were submerged for 30 days, followed by 30 days in drained soil; F30/ REA30 - plants were cultivated for 30 days in flooded soil, followed by 30 days in drained soil. During the experiment, flooded plants were kept with a $5 \mathrm{~cm}$ film of water over the soil and submerged plants had a $5 \mathrm{~cm}$ film of water over the tip of the plant. Ten plants were used at the beginning of the experiments for the initial estimate of plant dry mass. 


\section{Growth and development}

Ten plants were used in each treatment (dry soil for 30 days - D30; flooded for 30 days - F30; submerged for 30 days - SB30) where leaves were counted and the last totally expanded leaf was marked to evaluate the abscission rates and the formation of new leaves during the experiments. The dry mass of the plants was obtained for all treatments. To obtain the dry mass, the plants were divided into roots, stem and leaves, placed in a drying chamber at $60^{\circ} \mathrm{C}$ for $72 \mathrm{~h}$, and then weighed on a semi-analytic balance. The dry mass was used to calculate the relative growth rates (RGR) for all treatments using the following formula: $\mathrm{RGR}=\ln \left(\mathrm{Wt}_{1}\right)-\ln \left(\mathrm{Wt}_{0}\right) \mathrm{d}^{-1}$, where $W$ is the dry mass of the component at time $t$ and $d$ is the duration of the experiment. RGR was determined for root, stem, leaf, and the whole plant for all treatments. The leaf area of D60 and F60 plants was measured using a Li-Cor area meter model Li-300, for both populations (Londrina and Imbaú).

\section{Morphoanatomy}

One-centimeter sections from the transition region between root and stem and the proximal region of secondary roots were collected, fixed in $70 \%$ formalin acetic acid, dehydrated in an ethanol-xylol series and included in paraplast. Then, the blocks were sectioned at a thickness of 10 to $12 \mu \mathrm{M}$, and the sections were stained with astra blue and basic fuchsin and analyzed with an optical microscope (Luque et al., 1996). All the measurements were done using eight plants and one slide per plant. Histological measurements were made utilizing the Image Pro-Plus software.

\section{DNA extraction, amplification, and electrophoresis}

Leaf samples for DNA analysis were collected from 35 plants of each population (Imbaú and Londrina), with a minimal distance of $5 \mathrm{~m}$ from each other. Genomic DNA was isolated following the method of Doyle and Doyle (1987), except that CTAB was replaced by MATAB (mixed alyltrimethylammonium bromide, Sigma). DNA concentration was estimated using a fluorometer (DyNA Quant 200, Höefer-Pharmacia), according to manufacturer instructions. DNA samples of the 70 individual plants were adjusted to $10 \mathrm{ng} / \mu \mathrm{L}$ and used in the amplification reactions with a final volume of $15 \mu \mathrm{L}$ consisting of 1X PCR buffer (75 mM Tris- $\mathrm{HCl}, \mathrm{pH} 9.0,50 \mathrm{mM} \mathrm{KCl}, 2.0 \mathrm{mM} \mathrm{MgCl}{ }_{2}$, and 20 $\mathrm{mM}\left(\mathrm{NH}_{4}\right)_{2} \mathrm{SO}_{4}$ ), $0.2 \mathrm{mM}$ each of dATP, dTTP, dCTP, and dGTP; $0.4 \mu \mathrm{M}$ primer (Operon Technologies - OPAE-08, OPAE-12, OPAF-01, OPAF-02, OPAF-03, OPAF-04, OPAF-08, OPAF-13, OPAF-20, OPN-01, OPN-06, OPN-08, OPN-10, OPN-18, OPT-02, OPT-17, OPAW-05, OPAW-06, OPAW-07, OPW-01, OPW-06, OPW-09), 0.9 U Taq DNA Polymerase (Biotools), and $20 \mathrm{ng}$ template DNA. The thermal cycler was programmed for 3 min at $94^{\circ} \mathrm{C}$ for initial DNA denaturation, followed by 48 cycles of $1 \mathrm{~min}$ at $94^{\circ} \mathrm{C}, 1 \mathrm{~min}$ and $45 \mathrm{~s}$ at $38^{\circ} \mathrm{C}$, and $2 \mathrm{~min}$ at $72^{\circ} \mathrm{C}$. The last cycle was followed by a 7 -min extension at $72^{\circ} \mathrm{C}$. The samples were then stored at $4^{\circ} \mathrm{C}$ until electrophoresis. Amplified products were resolved on $1.4 \%$ agarose gels in $1 \mathrm{X}$ TAE buffer $(40 \mathrm{mM}$ Tris-acetate, $1 \mathrm{mM}$ EDTA, $\mathrm{pH}$ $8.0)$, at $120 \mathrm{~V}$ for $3 \mathrm{~h}$ and stained with ethidium bromide. The RAPD profiles were visu- 
alized under UV light, and photographed using a video camera (Cohu, high-performance CCD Camera).

\section{Statistical analysis}

The anatomical and morphological data were analyzed using analysis of variance (SAS, $1990)$ and the averages tested with the Tukey test $(\mathrm{P}<0.05)$. For RAPD analysis, the PCR profiles were tested for reproducibility and analyzed using only good-quality amplified fragments. Molecular markers were then assessed for the presence (1) or absence (0) of homologous DNA bands among all individuals of both populations. The percentage of polymorphic loci and genetic diversity (Nei, 1978) were calculated for both populations using the POPGENE software v. 1.31 (Yeh et al., 2000). To assess the genetic variation within and among populations and the fixation index $F_{S T}$, we used analysis of molecular variance (AMOVA) calculated with the ARLEQUIN software v. 2.0 (Schneider et al., 2000). The bootstrap method was applied using the DBOOT software v. 1.1 (Coelho, 2000) to evaluate the reliability of our results.

\section{RESULTS}

\section{Growth and development}

Schinus terebinthifolius was not affected by flooding, but total submersion proved to be lethal for $100 \%$ of the plants. Leaf abscission was not uniform during the 30 days of the experiment. It was greater in F30 than D30. Under submersion, plants from the Londrina population lost all their leaves and the population from Imbaú lost 95\% of their leaves. Plants from the Londrina population showed a significant decrease in the number of leaves after flooding for 60 days, although the leaf area did not differ between treatments. Plants of this population showed a greater leaf area when compared to the population from Imbaú (Table 1).

Table 1. Leaf number and leaf area in plants from two populations (Londrina and Imbaú) of Schinus terebinthifolius
cultivated for 30 days in drained (D30) and flooded (F30) soil.
\begin{tabular}{llcrrr}
\hline Parameters & \multicolumn{2}{c}{ Londrina } & & \multicolumn{2}{c}{ Embaú } \\
\cline { 2 - 5 } & D30 & F30 & & D30 & F30 \\
\hline Leaf number per plant & $21.42^{\mathrm{a}}$ & $13.28^{\mathrm{b}}$ & & $15.57^{\mathrm{b}}$ & $12.28^{\mathrm{b}}$ \\
Leaf area $\left(\mathrm{cm}^{2}\right)$ & $296.1^{\mathrm{ab}}$ & $348.43^{\mathrm{a}}$ & & $258.7^{\mathrm{b}}$ & $241.49^{\mathrm{b}}$ \\
\hline
\end{tabular}

Numbers followed by the same superscript letters in each line do not differ from each other by the Tukey test $(\alpha=$ $0.05, \mathrm{~N}=20$ ).

The flooding period did not affect the plant RGR in both populations. However, both populations showed a significant reduction in the RGR of leaves and the whole plant after submersion, and of stems in the Imbaú population. The root RGR did not differ among treatments (Table 2). We observed a negative correlation between hypoxia intensity and survival in S. terebinthifolius. Plants submitted to flooding followed by re-aeration showed $100 \%$ survival rate of individuals from both populations, whereas when submersion was followed by re-aeration the mortality rate was $100 \%$. 


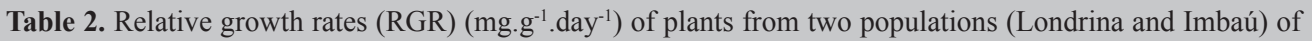
Schinus terebinthifolius cultivated in drained soil for 30 (D30) or 60 (D60) days; in flooded soil for 30 days (F30); submersed for 30 days (SB30); submersed for 30 days followed by 30 days in drained soil (SB30/ REA30); in flooded soil for 30 days followed by 30 days in drained soil (F30/REA30).

\begin{tabular}{lcc}
\hline Parameter & Londrina & Imbaú \\
\hline Root's RGR & & \\
D30 & $0.0150^{\mathrm{ab}}$ & $0.0060^{\mathrm{ab}}$ \\
F30 & $0.0112^{\mathrm{ab}}$ & $0.0010^{\mathrm{ab}}$ \\
SB30 & $0.029^{\mathrm{ab}}$ & $-0.0009^{\mathrm{ab}}$ \\
D60 & $0.0191^{1 \mathrm{ab}}$ & $0.0146^{\mathrm{ab}}$ \\
SB30/REA30 & $0.0048^{\mathrm{ab}}$ & $-0.0074^{\mathrm{b}}$ \\
F30/REA30 & $0.0225^{\mathrm{a}}$ & $0.0185^{\mathrm{ab}}$ \\
Stem's RGR & & \\
D30 & $0.0206^{\mathrm{ab}}$ & $0.0260^{\mathrm{a}}$ \\
F30 & $0.0114^{\mathrm{abc}}$ & $0.0120^{\mathrm{abc}}$ \\
SB30 & $0.012^{\mathrm{abc}}$ & $-0.039^{\mathrm{c}}$ \\
D60 & $0.021^{\mathrm{ab}}$ & $0.0246^{\mathrm{ab}}$ \\
SB30/REA30 & $0.0039^{\mathrm{bc}}$ & $-0.0064^{\mathrm{c}}$ \\
F30/REA30 & $0.0175^{\mathrm{ab}}$ & $0.0183^{\mathrm{ab}}$ \\
Leaves RGR & $-0.0009^{\mathrm{a}}$ & $0.1740^{\mathrm{a}}$ \\
D30 & $-0.0104^{\mathrm{a}}$ & $0.1760^{\mathrm{a}}$ \\
F30 & $-0.0562^{\mathrm{cd}}$ & $-0.2304^{\mathrm{c}}$ \\
SB30 & $0.0112^{\mathrm{b}}$ & $0.0247^{\mathrm{b}}$ \\
D60 & $-0.0529^{\mathrm{c}}$ & $-0.1042^{\mathrm{d}}$ \\
SB30/REA30 & $0.0005^{\mathrm{b}}$ & $0.0130^{\mathrm{b}}$ \\
F30/REA30 & $0.2399^{\mathrm{a}}$ & $0.2327^{\mathrm{ab}}$ \\
Whole plant & $0.2003^{\mathrm{abc}}$ & $0.2073^{\mathrm{ab}}$ \\
D30 & $-0.0208^{\mathrm{d}}$ & $-0.2353^{\mathrm{f}}$ \\
F30 & $0.1662^{\mathrm{bc}}$ & $-1614^{\mathrm{bc}}$ \\
SB30 & $-0.0443^{\mathrm{d}}$ & $-0.1180^{\mathrm{c}}$ \\
D60 & $0.1398^{\mathrm{c}}$ & $0.1481^{\mathrm{c}}$ \\
SB30/REA30 & & \\
F30/REA30 & & \\
\hline
\end{tabular}

Numbers followed by the same superscript letters in each column do not differ from each other by the Tukey test $(\mathrm{P} \leq 0.05, \mathrm{~N}=20)$.

\section{Morphoanatomy}

Development of hypertrophic lenticels was observed during the first week of flooding in S. terebinthifolius. The lenticels appeared as a soft mass that emerged from the base of the stems (Figure 1). The size and height of opening lenticels were significantly higher in flooded plants in both populations (Table 3).

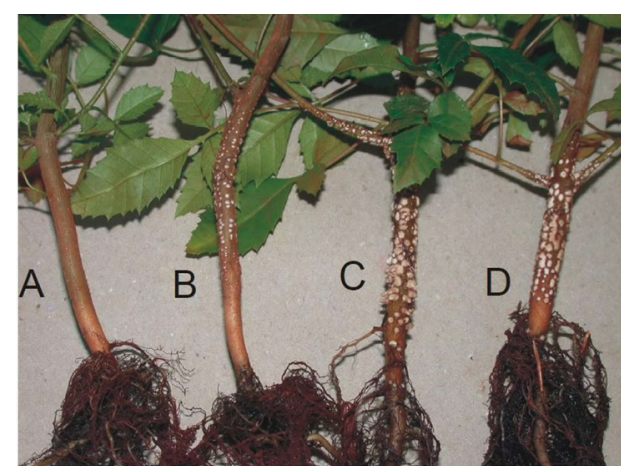

Figure 1. Schinus terebinthifolius. A. Cultivated in drained soil. B. Cultivated in flooded soil for 15 days. C. and D. Cultivated in flooded soil for 60 days. 
Table 3. Anatomical and morphological data for the transition region (TR) and secondary roots base (SR) of plants from two populations (Londrina and Imbaú) of Schinus terebinthifolius cultivated in drained (D60) and flooded (F60) soil for 60 days.

\begin{tabular}{|c|c|c|c|c|}
\hline & \multicolumn{2}{|c|}{ Londrina } & \multicolumn{2}{|c|}{ Imbaú } \\
\hline & D60 & F60 & D60 & F60 \\
\hline Lenticels opening $(\mu \mathrm{m})$ & $14.91^{\mathrm{c}}$ & $110.65^{\mathrm{b}}$ & $14.52^{\mathrm{c}}$ & $159.88^{\mathrm{a}}$ \\
\hline Lenticels height $(\mu \mathrm{m})$ & $11.62^{\mathrm{b}}$ & $55.41^{\mathrm{a}}$ & $14.39^{\mathrm{b}}$ & $83.35^{\mathrm{a}}$ \\
\hline Diameter $(\mu \mathrm{m})$ of vascular system in TR & $72.06^{\mathrm{b}}$ & $64.25^{\mathrm{ab}}$ & $89.44^{\mathrm{a}}$ & $61.94^{\mathrm{b}}$ \\
\hline Aerenchymatic areas $\left(\mu \mathrm{m}^{2}\right)$ in TR & $405.74^{\mathrm{a}}$ & $331.64^{\mathrm{a}}$ & $308.08^{\mathrm{a}}$ & $452.84^{\mathrm{a}}$ \\
\hline Diameter $(\mu \mathrm{m})$ of SR & $236.73^{\mathrm{a}}$ & $180.95^{\mathrm{a}}$ & $326.29^{\mathrm{a}}$ & $201.43^{\mathrm{a}}$ \\
\hline Number of aerenchymatic spaces in SR & $18.20^{\mathrm{ab}}$ & $23.90^{\mathrm{a}}$ & $13.80^{\mathrm{b}}$ & $26.40^{\mathrm{a}}$ \\
\hline
\end{tabular}

The same superscript letters in each line do not differ from each other by the Tukey test $(\mathrm{P} \leq 0.05, \mathrm{~N}=8)$.

Flooded plants from the Imbaú population showed greater openings for the lenticels than those from the Londrina population (Table 3). Flooded plants from the Imbaú population had the thickest vascular system in the transition region and a larger amount of aerenchymatic space in secondary roots than control plants. These differences were not observed between the treatments for the Londrina population (Table 3).

\section{Genetic diversity}

To evaluate the genetic variation in the two populations of $S$. terebinthifolius, 22 RAPD primers were applied to a sample of 70 individual plants, 35 from each population. A total of 181 markers were produced, of which 160 (88\%) were polymorphic. The coefficient of variation, estimated for the total number of markers, was lower than $5 \%$ (Figure 2).

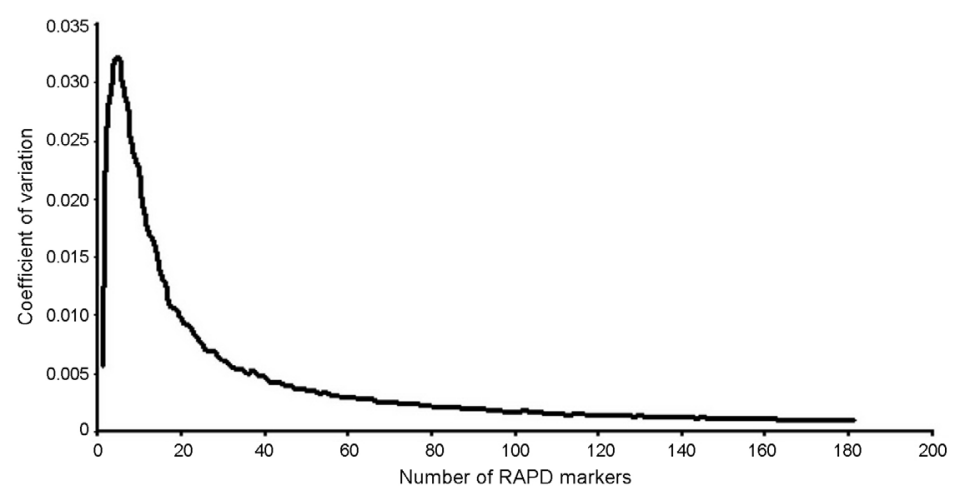

Figure 2. Bootstrap for the numbers of RAPD markers amplified in 70 individual Schinus terebinthifolius from two populations (Londrina and Imbaú).

The percentages of polymorphic loci and Nei's gene diversity were $70.72 \%, 0.1996$ and $64.64 \%, 0.1678$, for Imbaú and Londrina populations, respectively.

The AMOVA demonstrated that $13.72 \%$ of the genetic variation was between populations and $86.28 \%$ within the populations. The $F_{S T}$ value was 0.1372 indicating a moderate differentiation value between populations (Table 4). 


\begin{tabular}{|c|c|c|c|c|}
\hline Sources of variation & d.f. & Sum of squares & Variance components & $\%$ of variation \\
\hline Between populations & 1 & 95.833 & 2.43931 & $13.7^{*}$ \\
\hline Within populations & 64 & 981.515 & 15.33617 & 86.28 \\
\hline Total & 65 & 1077.348 & 17.775 & \\
\hline Fixation index & $F_{S T}$ & 0.13723 & & \\
\hline
\end{tabular}

$* \mathrm{P}<0.01$ (significance test given by 1023 permutations). d.f. $=$ degrees of freedom.

\section{DISCUSSION}

\section{Aspects of development}

Flooding did not affect the development of S. terebinthifolius, while total submersion caused a reduction in the development of the aerial portion of the plants. In Luehea divaricata, Carvalho et al. (2008) observed a reduction in the RGR of submerged plants. They considered that leaf abscission was responsible for this reduction, since apparently this organ is more vulnerable to flooding stress. When the whole plant is submersed, limitations for growth and survival greatly increase because of the significant depletion in oxygen and carbon dioxide, required for the photosynthetic process. Moreover, the photosynthetic process is also compromised by the reduction in the incidence of radiation on the leaves, since the light is attenuated exponentially as submersion depth increases (Crawford, 1992; Armstrong et al., 1994; Blom et al., 1994). The foliar abscission process can be abruptly accelerated in situations of water lodging in virtue of the high levels of ethylene in the plants (Bradford and Yang, 1980; Reid and Bradford, 1984). From our results, we may infer that S. terebinthifolius possesses strategies to eliminate the excess ethylene when flooded, although this does not occur during submersion.

Crawford and Braendle (1996) indicated that re-aeration of the plant tissues may cause the oxidation of anaerobic metabolic products, such as ethanol, which is oxidized into acetaldehyde; these and other substances formed during flooding, may be toxic to the plants. Moreover, under submersion, plant tissues are unable to eliminate excess products of anaerobic metabolism that may increase to highly toxic levels.

Hypertrophied lenticels, as observed in flooded plants of S. terebinthifolius, has been well documented in many plant species from temperate and tropical regions (Lobo and Joly, 1998; Bianchini et al., 2000; Mielke et al., 2005; Medri et al., 2002, 2007; Batista et al., 2008; Carvalho et al., 2008). The appearance of hypertrophied lenticels is associated with an increase in gas transport to areas with a deficit of $\mathrm{O}_{2}$ and with elimination of toxic gases, such as ethanol, acetaldehyde and ethylene, which increase considerably during flooding (Tsukahara and Kozlowski, 1985). Commonly hypertrophied lenticels are associated with large intercellular spaces in adjacent cortical layers (Hook and Scholtens, 1978) in stem and in tissues directly underneath the hypertrophied lenticels, as observed in Luehea divaricata (Carvalho et al., 2008), creating a mesh of gaseous transport from the aerated areas to the ones that have a deficit of oxygen due to submersion (Visser et al., 2003). In flooded plants of S. terebinthifolius that we observed, the development of hypertrophic lenticels was not associated with an increase in intercellular spaces in the transition region, although the secondary roots showed a greater amount of aerenchymatic space than in control plants. 
The capability and the extent of aerenchyma formation in roots have been directly associated with flood tolerance in many species (Justin and Armstrong, 1991). We found that S. terebinthifolius tolerates flooding but did not show developed aerenchyma, suggesting that other mechanisms promote the flooding tolerance. According to Moog (1998), roots with great quantities of aerenchyma do not possess enough physiologically active cells to sustain the main functions, such as mineral and water absorption, and storage of assimilated products. Therefore, plants with this anatomic root structure are unable to supply the high metabolic demands during the growth and development periods (Moog, 1998). As suggested by Moog and Janiesch (1990), flood-tolerant plants are capable of sustaining growth, even under waterlogged conditions, by maintaining a high ratio of active cortex cells in the roots.

\section{Genetic differentiation}

The low coefficient of variation for the number of markers revealed the high reliability of the results obtained with RAPD primers. The percentage of polymorphic loci and Nei's gene diversity was higher for the population from Imbaú $(70.72 \%$ and 0.1996$)$ than for the population of Londrina (64.64\% and 0.1678$)$. The higher genetic variation observed in the Imbaú population is probably due to the level of conservation of this area. This area presents a hilly landscape that makes the agricultural exploitation of this region almost impossible, contributing to the maintenance of a well-conserved forest fragment. The intra- and interpopulation variance coefficients, examined by AMOVA, showed that in S. terebinthifolius 13.7 and $86.3 \%$ of the variability were found between and within populations, respectively. Similar results have been observed in other natural Neotropical tree species (Gillies et al., 1999; Jordano and Godoy, 2000). The fixation index (Wright, 1951) calculated for S. terebinthifolius revealed an $F_{S T}$ value of 0.1372 , which according to Hartl and Clark (1988) indicates a moderate level of genetic divergence between the populations. Taking into account that these two populations are $180 \mathrm{~km}$ apart and that these regions are located at different altitudes (Londrina

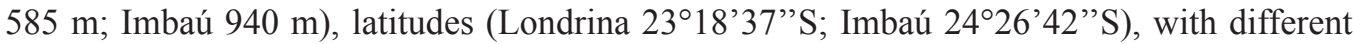
soils and climates, it is possible to infer that the values of $F_{S T}$ are related to different adaptation requirements of the plants to each specific region. RAPD markers applied to the study of the Neotropical tree species Swietenia macrophylla showed that similarities between populations of this species increased as geographical distance increased up to $1300 \mathrm{~km}$ and finally, similarities decreased again at $1500 \mathrm{~km}$ (Gillies et al., 1999). This does not follow a pattern of isolation by distance and may result from similar environmental conditions, such as soil type, precipitation and the number of dry months.

We observed that S. terebinthifolius plants exhibit tolerance to short periods of flooding with the development of anatomical alterations that permit survival under this type of stress. Such alterations allow plants to recover their aerobic metabolism and avoid death. However, some aspects of these alterations, such as the rate of lenticel openings and reduction of thickness of the central cylinder in roots, differentiated the two populations. These differences might also be partially responsible for the observed value of $F_{S T}$ between populations. The same pattern of behavior was observed by Carvalho et al. (2008) in Luehea divaricata.

Schinus terebinthifolius exhibited high and moderate genetic variability within and between populations, respectively, suggesting that the two populations are well conserved. While many plant species are threatened by selective logging and deforestation, the quantifi- 
cation of the genetic diversity and the monitoring of the impacts of waterlogging and habitat degradation on $S$. terebinthifolius offer practical information for the future use of this species in programs devoted to recovering degraded areas, including those exposed to flooding.

\section{ACKNOWLEDGMENTS}

The authors are grateful to Conselho Nacional de Pesquisa (CNPq) (Process \#478179/2006-5) and Fundação Araucária (Convênio \#064/2007) for financial support and Coordenação de Aperfeiçoamento de Pessoal de Nível Superior (CAPES) for the grants to E.A. Ruas.

\section{REFERENCES}

Armstrong W (1980). Aeration in higher plants. Adv. Bot. Res. 7: 225-332.

Armstrong W, Brändle R and Jackson MB (1994). Mechanisms of flood tolerance in plants. Acta. Bot. Neer. 43: 307-358. Batista CUN, Medri ME, Bianchini E, Medri C, et al. (2008). Flood tolerance in Cecropia pachystachya Trec. (Cecropiaceae): ecophysiological and morpho-anatomical aspects. Acta Bot. Bras. 22: 91-98.

Bianchini E, Medri ME, Pimenta JA, Giloni PC, et al. (2000). Anatomical alterations in plants of Chorisia speciosa A. St.- Hill. submitted to flooding. Interciencia 25: 436-411.

Blom CWPM, Voesenek LACJ, Banga M, Engelaar WMHG, et al. (1994). Physiological ecology of riverside species: adaptive responses of plants to submergence. Ann. Bot. 74: 253-263.

Bradford KJ and Yang SF (1980). Stress-induced ethylene production in the ethylene-requiring tomato mutant diageotropica. Plant Physiol. 65: 327-330.

Carvalho MCCG, Da Silva DCG, Ruas PM, Medri ME, et al. (2008). Flooding tolerance and genetic diversity in populations of Luehea divaricata. Biol. Plantarum 54: 771-774.

Chen H, Qualls RG and Miller GC (2002). Adaptive responses of Lepidium latifolium to soil flooding: biomass allocation, adventitious rooting, aerenchyma formation and ethylene production. Environ. Exp. Bot. 48: 119-128.

Coelho ASG (2000). Dboot: Avaliação dos Erros Associados a Estimativas de Distâncias/Similaridades Genéticas Através do Procedimento de Bootstrap com Número Variável de Marcadores (Software). Universidade Federal de Goiás, Instituto de Ciências Biológicas, Laboratório de Genética Vegetal, Goiânia.

Crawford RMM (1992). Oxygen availability as an ecological limit to plant distribution. Adv. Ecol. Res. 23: 93-185.

Crawford RMM and Braendle R (1996). Oxygen deprivation stress in a changing environment. J. Exp. Bot. 47: 145-159.

Davanso-Fabro VM, Medri ME, Bianchini E and Pimenta JA (1998). Tolerância à inundação: aspectos da anatomia ecológica e do desenvolvimento de Sesbania virgata (Cav.) Pers. (Fabaceae). Braz. Arch. Biol. Technol. 41: 475-482.

Doyle JJ and Doyle JL (1987). A rapid DNA isolation procedure for small quantities of fresh leaf tissue. Phytoch. Bull. 19: 11-15.

Ferreira ME and Grattapaglia D (1996). Introdução ao Uso de Marcadores Moleculares em Análise Genética. 2nd edn. Embrapa-Cenargen, Brasília.

Gillies AC, Navarro C, Lowe AJ, Newton AC, et al. (1999). Genetic diversity in Mesoamerican populations of mahogany (Swietenia macrophylla), assessed using RAPDs. Heredity 83 (Pt 6): 722-732.

Guerra MJM, Barreiro ML, Rodriguez ZM and Rubalcada Y (2000). Actividad antimicrobiana de un extracto fluido al $80 \%$ de Schinus terebinthifolius Raddi (COPAL). Rev. Cubana Plant Med. 5: 23-25.

Hartl DL and Clark AG (1988). Principles of Population Genetics. Sinauer Associates, Sunderland.

Hook DD and Scholtens JR (1978). Adaptations and Flood Tolerance of Tree Species. In: Plant Life in Anaerobic Environments (Hook DD and Crawford RMM, eds.). Ann Arbor Science Publishers, Michigan, 299-331.

Jordano P and Godoy JA (2000). RAPD variation and population genetic structure in Prunus mahaleb (Rosaceae), an animal-dispersed tree. Mol. Ecol. 9: 1293-1305.

Justin SHFW and Armstrong W (1991). Evidence for the involvement of ethylene in aerenchyma formation in adventitious roots of rice (Oryza sativa L.). New Phytol. 118: 49-62.

Lenzi M and Orth AI (2004). Characterization of the functional reproductive system of the pink-pepper (Schinus terebinthifolius Raddi), in Florianópolis, SC, Brazil. Rev. Bras. Frutic. 26: 198-201.

Lobo PC and Joly CA (1998). Tolerance to hypoxia and anoxia in Neotropical tree species. Oecol. Bras. 4: 137-156.

Lorenzi H (2002). Árvores brasileiras: manual de identificação e cultivo de plantas arbóreas nativas do Brasil. 2nd edn. Instituto Plantarum, Nova Odessa.

Luque R, Sousa HC and Kraus JE (1996). Métodos de coloração de Roeser (1972) - modificado - e Kropp (1972) visando 
a substituição do azul de astra por azul de alcião 8GS ou 8GX. Acta Bot. Bras. 10: 199-212.

Medri ME, Bianchini E, Pimenta JA, Colli S, et al. (2002). Estudos sobre a Tolerância ao Alagamento em Espécies Arbóreas Nativas da Bacia do Rio Tibagi. In: A Bacia do Rio Tibagi (Medri ME, Bianchini E, Shibatta OA and Pimenta JA, eds.). Edição dos Editores, Londrina, 133-172.

Medri ME, Ferreira AC, Kolb RM, Bianchini E, et al. (2007). Morpho-anatomical alterations in plants of Lithraea molleoides (Vell.) Engl. submitted to flooding. Acta Sci. Biol. Sci. 29: 15-22.

Melo J, Amorim E and Albuquerque U (2009). Native medicinal plants commercialized in Brazil - priorities for conservation. Environ. Monit. Assess. 156: 567-580.

Mielke MS, Almeida AAF, Gomes FP, Mangabeira PAO, et al. (2005). Effects of soil flooding on leaf gas exchange and growth of two Neotropical pioneer tree species. New Forests 29: 161-168.

Moog PR (1998). Flooding tolerance of Carex species. I. Root structure. Planta 207: 189-198.

Moog PR and Janiesch P (1990). Root-growth and morphology of Carex species as influenced by oxygen deficiency. Funct. Ecol. 4: 201-208.

Nei M (1978). Estimation of average heterozygosity and genetic distance from a small number of individuals. Genetics 89: 583-590.

Reid DM and Bradford KJ (1984). Effects of Flooding on Hormone Relations. In: Flooding and Plant Growth (Kozlowski TT, ed.). Academic Press, London, 195-219.

Schneider S, Roessll D and Excoffier L (2000). ARLEQUIN: A Software for Population Genetics Data Analysis, Version 2.0. Genetics and Biometry Laboratory, Department of Anthropology, University of Geneva, Geneva.

Statistical Analysis Systems (SAS) (1990). SAS Procedures Guide. SAS Institute Inc., Cary.

Tsukahara H and Kozlowski T (1985). Importance of adventitious roots to growth of flooded Platanus occidentalis seedlings. Plant Soil 88: 123-132.

Visser EJW, Voesenek LACJ, Vartapetian BB and Jackson MB (2003). Flooding and plant growth. Ann. Bot. 91: 107-109.

Voeseneck LACJ and Van der Veen R (1994). The role of phytohormones in plant stress: too much or too little water. Acta Bot. Neerl. 43: 91-127.

Wright S (1951). The genetical structure of populations. Ann. Eugenics 15: 323-354.

Yeh FC, Yang R, Boyle TJ, Ye Z, et al. (2000). PopGene32, Microsoft Windows-based Freeware for Population Genetic Analysis, Version 1.32. Molecular Biology and Biotechnology Centre, University of Alberta, Edmonton. 